Journal of

\title{
Education and Practice
}

(JEP)

THE ANALYSIS OF PRESCRIBED PEDAGOGY PRACTICES FOR DESIGN AND TECHNOLOGY IN ZAMBIAN SCHOOLS.

THE CASE OF CHIPATA DISTRICT
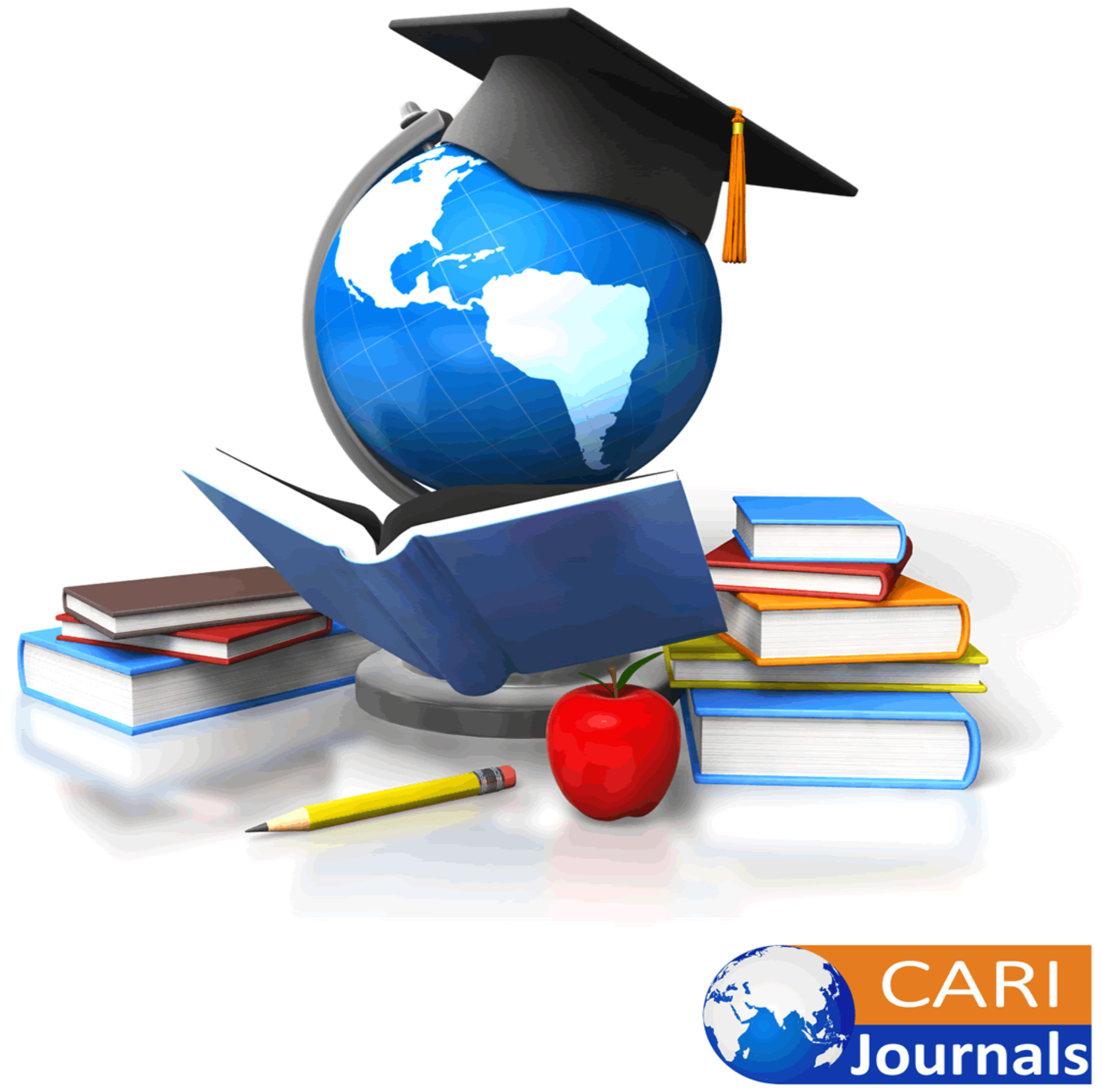
Journal of Education and Practice

ISSN 2520-467X (Online)

Vol.5, Issue No.2, pp 1 - 17, 2021

www.carijournals.org

\title{
THE ANALYSIS OF PRESCRIBED PEDAGOGY PRACTICES FOR DESIGN AND TECHNOLOGY IN ZAMBIAN SCHOOLS. THE CASE OF CHIPATA DISTRICT
}

\author{
1*Mabvuto Dweku Mhango \\ Mufulira College of Education. Zambia. \\ Corresponding Author's email: mmabvutodweku@gmail.com \\ ${ }^{2 *}$ Dr. Dickson. D Ndenguma. \\ University of Malawi: The Polytechnic College \\ Corresponding Author’s email: dndenguma@poly.ac.mw \\ ${ }^{3 *}$ Mr. M. Mnelemba. \\ University of Malawi: The Polytechnic College \\ Corresponding Author’s email: mmnelemba@poly.ac.mw
}

\begin{abstract}
Purpose: The study delved into prescribed pedagogy practices for Design and Technology in Zambian schools, "Chipata district in particular". The main objective of this study was to contribute towards a comprehensive understanding of the prescribed pedagogies in the syllabus of Design and Technology. Thus, the rationale of the work is based on the application of prescribed pedagogies by practicing teachers for Design and Technology in the teaching and learning process in secondary schools. The, aim of the study is to analyse the application of the prescribed methods by teachers of Design and Technology. The research was undertaken in order to assess the application of the prescribed pedagogy in the newly rolled out curriculum for Design and Technology. This was on the premise that the curriculum was implemented without retraining of the subject teachers. The study covers three selected schools, from which six practicing teachers and three pupils were interviewed.

Methodology: Data was collected through interviews, documented records used by the teachers and class observation. The collected data was analysed manually and through the use of qualitative data analysis (QDA) miner lite. During the data analysis themes emerged which served as a guide for discussion.

Results: The study indicates that teachers need more orientation of the pedagogies in the syllabus to fully utilise them. Further, results show that there is need to enhance teacher content knowledge and ensure the availability of teaching and learning resources. For the sake of good application of the pedagogies the study recommends: orientation of teachers on prescribed teaching methods, provision of standard workroom, enough teaching and learning resources, and upgrading teacher qualifications.
\end{abstract}


Journal of Education and Practice

ISSN 2520-467X (Online)

Vol.5, Issue No.2, pp $1-17,2021$

www.carijournals.org

Unique contribution to theory, policy, and practice: Teachers need to read and understand the new syllabus demands for them to apply the prescribed pedagogies as required. Additionally it is great importance to orient teachers adequately before the new syllabus is rolled out. Therefore there is need to a deliberate program to retrain teachers or organize continuous professional development programs so that they are acquainted to new pedagogies.

Keywords: Design and Technology, pedagogies, competencies, continuous professional development programme (CPD)

\subsection{INTRODUCTION}

Design and Technology (D\&T) is an important subject as it is well aligned with technological applications and development. If effectively taught, it would inspire pupils to take up technology/ engineering as careers. Thus, from the onset, the content, pedagogies, and the learning environment play a critical role in the future of the child. Often, the mode of teaching does not respond to the needs and aspirations of learners (Kushner, Benson \& Ward, 2013). Design and Technology can be defined as finding solutions to a situation and applying the technology to the develop a product that responds to it.

Design and Technology may consist of one subject or a combination of certain disciplines which include Mathematics and Science. This subject or the combination is perceived as challenging not only among learners but also some teachers. This notion may largely influence the attitudes and perceptions of both teachers and learners towards teaching and learning of the subject. On one hand, technology subjects are seen as secondary by the students whilst the community views the deficiencies in a way technology subject are taught (Haynes, 2008).

Khunyakari, (2015) explains that world over, the D\&T subject is taught at primary and secondary school levels with a view to develop in learners' manipulative and critical thinking skills. Learners design and make artifacts, following a standard design process. It is this process that must be taught comprehensively to enable the learners respond to societal needs positively. Therefore, learners must be provided with a good learning environment to fully tap their practical abilities (Williams, 2012). This is only possible through application of a good pedagogy during lesson delivery. A good pedagogy application does not only bring out the interaction between teachers, learners, and learning environment, but also the learning tasks (Lucas, 2014). Teachers must therefore endeavor to find and apply suitable pedagogies for the lessons.

In Zambia, Design and Technology is a new subject which was previously called Industrial Arts, which was comprised of Metalwork, Woodwork, and Technical Drawing. It was taught in secondary school only. To date, the subject has undergone substantial changes from its name to content, not leaving out the pedagogy to be used. Unlike other subjects, changes in technology remarkably influence the curriculum of D\&T (Lucas, Spencer, \& Claxton, 2012). Design and Technology provides teaching of diverse competencies to learners, these need different applications of pedagogies. It is from this background that (Pamies., Blanco, Sanchez,. \& Villanueva, 2015) propose the need for developing a common training for teachers and pedagogies so that they can work in interdisciplinary groups. A competency is defined as "the 
Journal of Education and Practice

ISSN 2520-467X (Online)

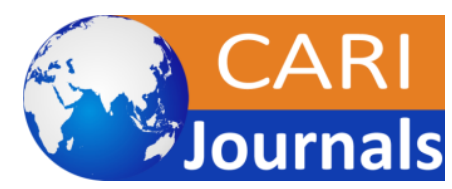

Vol.5, Issue No.2, pp $1-17,2021$

WwW.carijournals.org

capacity to answer complex demands and to work in an appropriate way involving the ability to meet complex demands, by drawing on and mobilizing psychosocial resources in a particular context" (OECD, 2002: 4). This definition provides an array of what is involved in the Design and Technology subject. But the methods used in the teaching of Design and Technology, are still those that were used in Industrial Arts.

Subsequently, this perpetual shifting of curriculum content and fluctuating knowledge and skills base that manifests, perpetuates subject instability and presents it as a subject with weak, poorly defined external boundaries as compared to other Science technology Engineering and Mathematics (STEM) subjects (Bell, Wooff, Mclain, \& Morrison, 2017). It must be noted the frequent changes in the curriculum result in some resistance from some teachers.

In the SADC region, some countries offer technology education, despite a shortfall of qualified teaching staff. This is because of the importance attached to the subject. However, in case of lack of training facilities, teachers are sent to retrain in countries where training is offered (Gaotlhobogwe , 2014). In earnest the importance of technology education should not be undervalued in this era of technology development and innovation. In fact, ministers from SADC recognise the need of involving the industry to make D\&T curricula responsive to emerging technological evolution (SADC, 2018). Truly this can bring to the fore valuable pedagogies for intended competencies. Actually the University chancellors of the SADC region hinted on the need to change the Design and Technology education system to make STEM effective for industrialization, (Mukereredzi, 2019).

In Zambia, a mismatch was evident in teaching of practical subjects to what was prevailing in the industry (Kelly, 1999). This could have been because the curriculum did not match with society and the industry demands. However, a competency-based curriculum seemed to be an answer to the needs of the community, it was ready in 2013 and it was implemented in schools in 2014. Design and Technology is the curriculum that was designed to mitigate some situations. It is assumed that a competence-based curriculum approach helps enhance students' academic achievement (Makunja, 2015). This was done in line with the policy document 'Educating our Future 1996' where the importance of skill learning is seen to be critical in an individual's life (Ministry of Education, 1996).

Implementation of the competence-based curriculum was done without re-training of teachers, this was despite changes it came with. This has posed a challenge to teachers in terms of teacher content pedagogy application. Nonetheless, teachers must be abreast with the pedagogies outlined in the syllabus if their teaching is to be effective (Lucas, 2014). Teachers must be diligently trained on how to articulate these methods judiciously. Moreover, "Competency-based curriculum requires teachers to have clarity of focus, reflective designing, setting high expectations for all learners" (Ministry of Education S. V., 2013). A teacher must, therefore, explore more tasks to give the learner so that they develop confidence in what they are taught.

There is a problem in applying prescribed pedagogy in teaching D\&T globally by teachers. This could be as a result of the many transitions the subject has been going through. This has made 
Journal of Education and Practice

ISSN 2520-467X (Online)

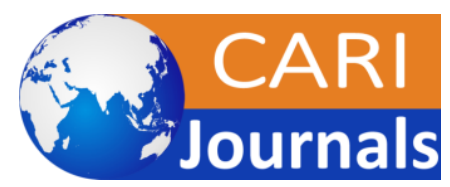

Vol.5, Issue No.2, pp 1 - 17, 2021

WwW.carijournals.org

teachers have challenges to effectively apply the prescribed pedagogy (Moalosi \& Molwane, 2008). In most cases teachers are ill prepared to teach the subject emanating from the changes. Besides, the resistance from some teachers cannot be ruled out. Thus, some teachers may not be ready to meet the new challenges, some may take long to accept the changes whilst others insist on old teaching approaches. These negatively impact on the application of newly introduced pedagogies of the subject delivery

This study was aimed at analysing, in the broad perspective, the application of selected pedagogies used in teaching and learning of design and technology by attempting to identify the pedagogies used, assessing the subject matter and materials for learners. Therefore, the purpose of the study was to analyse the application of the selected prescribed methods by teachers of design and technology.

\subsection{Problem Statement}

Design and Technology subject is a subject that can provide economic sustainability to individuals during and after the learning time. It develops in learner's critical thinking and analysis on how to look at the problems they meet in society. Furthermore, the education policy in Zambia emphasises on the importance of life skills, this led to the introduction of D\&T in Zambian schools under the vocational pathway (Ministry of Education S. V., 2013). But the subject is new and teachers are adjusting to how they can teach the subject better. Yet, if the subject pedagogies are well applied, it can create an impact in the society. This study will enable teachers understand the importance of application of the prescribed pedagogies in teaching Design and Technology subject. Moreover, from my teaching experience in Zambia, there is a concern about the use of prescribed pedagogy and teacher practices for teaching Design and Technology. This view is espoused through observation that shows a limited or no teacher orientation and or retraining before the syllabus was rolled out (MOGE, 2014).

\subsection{Research Objectives}

The following objectives and questions were used:

1. To determine which pedagogies are customarily applied during teaching of Design and Technology.

2. Probe how prescribed pedagogies are applied in the teaching and learning process of design and technology in secondary schools.

\subsection{Research Questions}

1. Which pedagogies do teachers mostly use during the teaching of design and technology?

2. How are prescribed pedagogies applied in teaching Design and Technology in secondary schools?

The research endeavoured to provide solutions to present challenges concerning the delivery of D\&T subject especially issues to do with application of prescribed pedagogy. It provided 
Journal of Education and Practice

ISSN 2520-467X (Online)

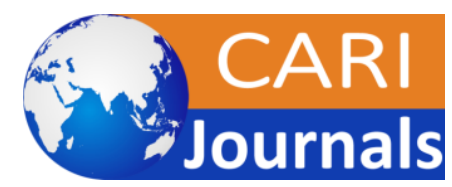

Vol.5, Issue No.2, pp $1-17,2021$

www.carijournals.org

information on how much teachers understand the prescribed pedagogies and competences in the syllabus.

Additionally, pupils will benefit because their teachers who have the knowledge that makes them select desirable pedagogy for their lessons and class activities. Policymakers to be aware of the deficits in teacher lesson preparation and presentation. Thus these findings can be used to lobby the government for funds to re-train teachers and organise continuous professional development (CPD) meetings.

\subsection{LITERATURE REVIEW}

\subsection{Introduction}

A good pedagogy application is the basis of good teacher practices for design and technology teaching. It is in this regard that teachers are well grounded in content knowledge and the requirements of the curriculum.

In Zambian schools, design and technology is a new subject which was rolled out in 2013. It demands the teaching of knowledge, skills and values to learners. This was all done to make the subject relevant and responsive to current trends. The introduction of D\&T was done with a view that upon completion of secondary school learners acquire skills and an academic certificate (Nkanza, 2014). Thus, learners are expected to obtain appropriate knowledge, skills, attitudes; values and problem-solving ability to enable them solve the ever-changing needs of society. In this view, suitable use of the prescribed pedagogy is important for teaching skills because it unlocks the minds of learners, as a consequence apply the knowledge in their daily livelihood (Lucas, 2014). It is for this reason that the syllabi are designed with numerous recommended techniques for lesson deliveries. For instance, the Zambian D\&T syllabus has the following commended pedagogies in the syllabus; inquiry, problem-solving, project, collaborative, team teaching and group work (Ministry of Education S. V., 2013). Ultimately, the availability of these pedagogies provides a basis for good lesson delivery. It is essential therefore, that when new syllabi are introduced, teachers are oriented well before its implementation. Undeniably, the orientation is the foundation for good application of prescribed pedagogies.

\subsection{Pedagogical skills application in teaching design and technology}

Good pedagogy application is a premise of attaining fine learning outcomes. A teacher who uses of good pedagogy, makes it easy for learners to comprehend the concepts in a lesson. As a result, it is imperative that teachers undergo a rigorous orientation whenever new teaching methods are introduced. This is to enable the teacher to have an in depth comprehension of the newly introduced pedagogies for appropriate application during lesson delivery (Saleh, Rasul \& Affadi, 2018). Most of all, this equips the teacher with the knowledge on how to implement the curriculum with expertise. Moreover, pedagogical practices of the teacher trainees of design and technology are more often lecture method as opposed to doing a lot of practical activities (Saleh etal, 2018). From this, it is clear that during training, teacher trainers do little to develop skills for teaching D\&T in their trainees. As a consequence, most of them have challenges with the 
Journal of Education and Practice

ISSN 2520-467X (Online)

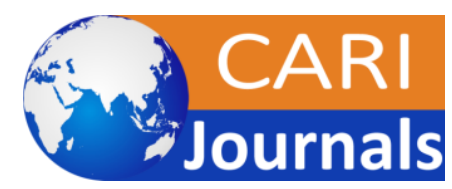

Vol.5, Issue No.2, pp $1-17,2021$

WwW.carijournals.org

application prescribed pedagogy recommended in teaching Design and Technology. This research attempted to analyse the teaching practices of Design and Technology teachers in secondary schools of Zambia with regards to prescribed pedagogies application provided in the syllabus.

Pedagogy for teaching STEM subjects in other parts of the world is well supported by the use of technology through simulations and videos (Carbonilla Gorra \& Bhati, 2016). This is because it brings reality in class and enhances pupils' understanding. Suffice to mention that, application of such technology for teaching in most developing countries is unavailable. But technology alone is not adequate to improve teaching and learning (Koehler \& Mishra, 2005). This implies that complementary approaches must be applied in lesson delivery. Consequently, if a teacher understands the pedagogies, they can choose which one to apply for a specific lesson.

\subsection{Competence-Based Learning in D\&T and Teacher Retraining}

Design and technology demand that the competences are attained by learners upon completion of their learning time. As such to effectively teach competences, teachers need to have the necessary expertise in the application of he prescribed pedagogies. Good teaching practices and application of pedagogies require that teachers are retrained in order to upgrade their proficiency.

Design and technology is one of the subjects in the competence curriculum which has evolved from Industrial Arts ((Kafyulilo, Rugambuka, (2013) \& Makunja, (2015)), 2018). Being a new subject, most teachers face challenges in teaching due to several segments that make up the subject. The domains that make up D \& T include material and processes wood, material and processes metal, electrical engineering, bricklaying, systems technology, graphic communication, and entrepreneurship. In a Zambian scenario, a teacher must teach all domains.

Retraining of teachers is however cardinal if the competency-based syllabus is to achieve its intended outcomes. Actually, without retraining, teachers have been facing a lot of challenges in the execution of the syllabus. For instance, the introduction of a competence-based curriculum in Tanzania and Rwanda made them realise that retraining of teachers is important for effective execution of the curriculum (Kafyulilo et al (2013) \& Makunja (2015)). This implies that at inception, teachers handled the subject using the previous methods which did not yield the intended results. As a result, the Tanzanian government organized training programs that addressed teachers' inability to use assessment data to identify students' learning needs and teachers' ability to respond to students' needs (Ngendahayo \& Askell-Williams, 2016). This was done to equip teachers with necessary teacher practices as provided in the curriculum to make them teach better.

Similarly, Zambia is not exceptional, teachers need to be retrained if the application of prescribed pedagogies in D\&T syllabus are to achieve the set goals intent. Hence, the retraining of teachers is required for the effective execution of the syllabus. The emphasis of the new curriculum is about the acquisition learners of knowledge, skills, and values (KSV) after the learning period. Therefore, teachers must fully understand the syllabus requirements as they choose pedagogy to apply from those prescribed. It must be realised that the failure to apply 
Journal of Education and Practice

ISSN 2520-467X (Online)

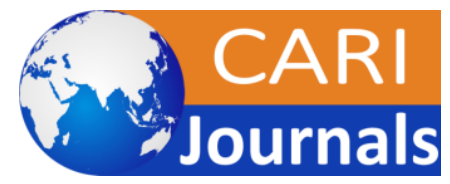

Vol.5, Issue No.2, pp $1-17,2021$

www.carijournals.org

competency-based teaching pedagogies deter learner's progression in acquiring necessary skills (Makunja, 2015). The need to understand the syllabus

In Zambia, secondary school curriculum for D\&T requires that at the end of the learning period the learners must show the following competencies: investigative skills, interpretational skills, application skills, communication skills, valuing skills, and participating skills (Ministry of Education S. V., 2013). Certainly, not knowing the competencies in the syllabus can lead to poor selection of the pedagogy, hence mediocrity in teaching. However, what is vital is the ability of teachers to teach these abilities at least to a required standard. Likewise, the role and expertise of teachers are critical because they are at the frontline of designing and delivering the learning experience (Eady \& Lockyer, 2013). Consistency in the application of pedagogy and content is a requirement for the curriculum outcomes are to be met.

\subsection{Preference of certain pedagogies to others}

To achieve the intended learning outcomes, the application of good pedagogy and well-laid content is indispensable. The use of the same pedagogy during the teaching of D\&T must be avoided because of the monotony it brings. Therefore, an eclectic approach is a better way to organise the teaching. The use of the same pedagogy at times is a result of the incapacity to apply other pedagogies by teachers. Varied pedagogy application brings out interest, motivation and engagement with the learners. This eventually enhances their' performance and achievement. The importance of the use of different methods is surely critical but the teacher needs to make a good judgment for appropriate methods to meet the needs for syllabus (Jalbani, 2014).

Appropriate application of prescribed pedagogy with rich content knowledge is a robust way that improves learner's acquisition of information during lesson delivery. Good methods of teaching and teacher practices do promote good learning and depth in understanding (Husbands, 2012) . Thus, good pedagogy provides a good foundation for learners in terms of creativity and innovation. It is for this reason that teachers choose a pedagogy that brings out achievement of intended outcomes, but practice and training enhance their abilities. One way, teachers can empower their students with creativity is by making them feel valued for being themselves (Broom, 2015). Moreover, pedagogies choice must provide a scaffolding platform for learners for their next lesson and other activities to follow.. But this is dependent on what teachers know and believes in.in actual fact, pedagogical practices that teachers bring out are as a consequence of their strength in the subject matter. Certainly, a teacher's belief is a basis of the preference of which pedagogies are applied for lesson delivery. For instance, teachers with a "constructivist mind" believe that learners must are active participants in the process of acquiring knowledge (OECD, 2009).

Masterly of the content by the teacher is critical because it enables them to command authority and have the confidence as they apply the pedagogies. What is important in teaching is realising that a combination of pedagogy and content are inevitable for a teacher. In fact, good teacher practices enable a teacher to choose better pedagogy for the achievement of intended outcomes 
Journal of Education and Practice

ISSN 2520-467X (Online)

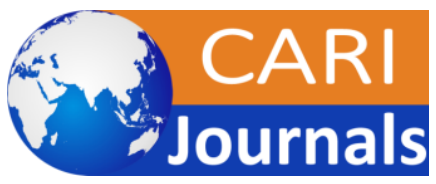

Vol.5, Issue No.2, pp 1 - 17, 2021

www.carijournals.org

in a given lesson. Good pedagogy therefore unlocks learners thinking, and provides hands-on, creative experience and develops a practical identity and a capability for innovation (Morgan, et al, 2013). Importantly, a good mastery of content is a basic tool a teacher uses to choose which pedagogy should be applied for a given lesson.

\subsection{Theoretical Grounding of the Study}

Despite many frameworks available, this research considered the Technological Pedagogical Content Knowledge (TPACK) and the "Archway of Meaningful Learning" as lenses for its discussion. TPACK provides authenticity during teaching and learning leading to high achievement by leaners due to high levels of interaction (Baran etal, 2011). The framework provides the basis for teachers to integrate knowledge into lesson delivery towards the achievement of intended outcomes. The legitimacy from the use of technology is what lacks in many schools in Zambia, in fact very few schools if any apply the technology in teaching. Problem-solving is at the centre of knowledge gaining in design and technology learning. This is provided through the use of the archway for meaningful learning which emphasises critical thinking and reasoning (Kelley T. \& Kellan, 2009).

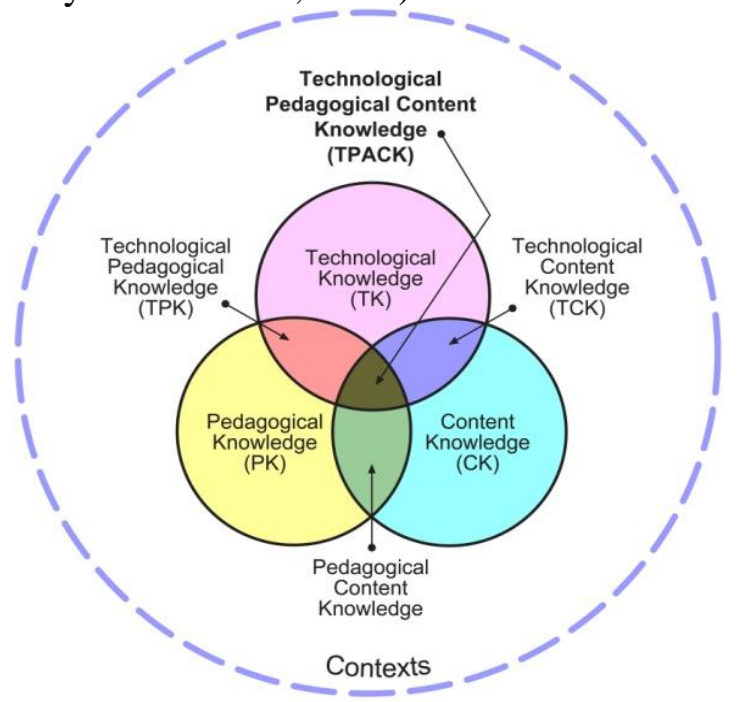

Figure 1: TPACK framework (Mishra, Khoehler, \& Zhao, 2007)

The TPACK shown in Figure 1, is an intersection of three regions, technological expertise, content material understanding and pedagogical know-how (Kushner, 2013). Thus, whatever a teacher does in class calls for help from the alternative regions. What is certain is that no one area is exclusively independent of the other in lesson preparation and delivery.

Meanwhile, The Archway of Meaningful Learning framework fits well with the teaching of Design and Technology (Kelley, \& Kellam, 2009), this is in line with what is involved in it. The framework promotes the constructivist model of learning (learner-centered/pragmatic), which is a requirement in the teaching of $\mathrm{D} \& \mathrm{~T}$ 
Journal of Education and Practice

ISSN 2520-467X (Online)

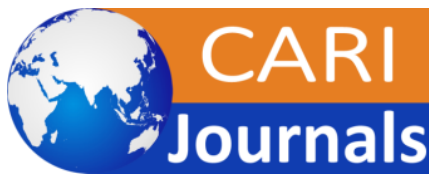

Vol.5, Issue No.2, pp $1-17,2021$

www.carijournals.org

A combination of the two frameworks makes it easy for the teacher to prepare D\&T lessons and achieve the intended outcomes. These frameworks were used in this study to analyse in-depth the application of prescribed pedagogy by the teacher during lesson delivery.

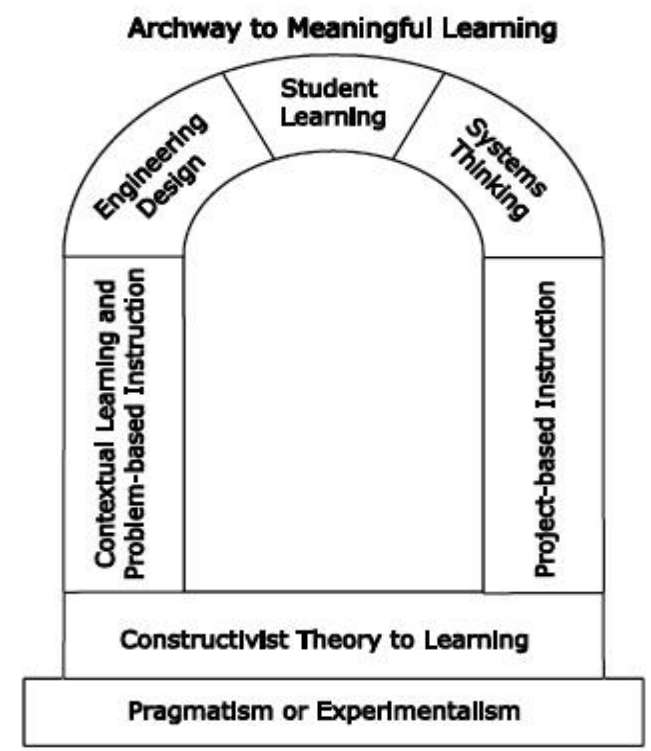

Figure 2: Archway of meaningful learning (Kelley, 2009)

This is typical learning of the D\&T class where learners work on situations to find solutions. In this regard, through the framework the researcher pursued whether the pedagogy used provides a basis of critical thinking in learners. Furthermore, through the frameworks, teachers can choose pedagogy that promotes learner interaction (Kelley, 2009; \& Schunk, 2012).

The archway of meaningful learning and TPACK complement each other well in lesson preparation and delivery for Design and Technology. TPACK looks at what a teacher needs to do for a lesson while the archway of meaningful learning has the learner at the centre. Making sure that what has been learned is translated into reality. The notion of problem-solving as a way of gaining knowledge is the basis of teaching which works out well for competence-based learning. This involvement of the learner is what empowers them to develop the intended skills which are sustainable.

\section{Research Gap}

Some similar studies have been recounted such as "Pedagogical Practices of design and Technology Teacher Trainees" by (Saleh etal, 2018), "Pedagogical Practices" by Dr. Radhika Kapur. Design and Technology is a newly introduced subject in Zambia. With this background there could be little or no information on how the subject is taught. Application of the prescribed pedagogies could indeed be a sure way of achieving the intended goals of the community from the subject. There is no study the has looked at the application of pedagogies in Design and Technology in Zambia. 
Journal of Education and Practice

ISSN 2520-467X (Online)

Vol.5, Issue No.2, pp 1 - 17, 2021

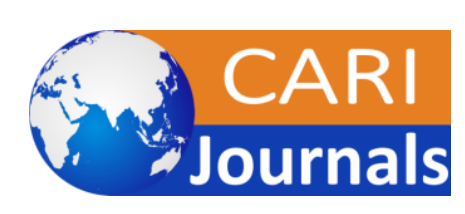

www.carijournals.org

\subsection{METHODOLOGY}

\subsection{Study Area}

The study setting was in Chipata District of Eastern province in Zambia. The schools that were involved in the study included two single sex schools and one mixed

\subsection{Research Design}

Research designs are critical in determining which methods should be used in data collection for particular research. A qualitative research approach was used to accomplish the objectives of the research. Moreover, the small sample consequently makes it difficult to generalize on pedagogy applications in a broader sense. In this approach, the sample used was small, and the outcomes are neither measurable nor quantifiable. In line with the research paradigm (constructivist), the research design was phenomenology. Phenomenology is highly concerned with how participants feel about things during an event within a particular group (Astalin, 2013). The respondents in the research were those that comprehend the subject matter with proficiency

\subsection{Approaches for Data Collection}

To manage comprehensive data collection the approach used was qualitative. Qualitative research uses several methods which involve interpreting, a naturalistic approach to its subject matter (Noien \& Talbert, 2011) \& (Marczyk DeMatteo \& Festinger, 2005)). This provided a deeper understanding of how the teaching of Design and Technology approaches were managed. Most of all, this approach was preferred to analyse the problem and provide ways of how to find solutions to the identified problem.

\subsection{Data Collection Method}

The methods used for data collection for this research included structured interviews, observations; teaching files and recording. Guided interviews enabled the interviewees to focus answers on the subject under discussion. These methods were carefully selected considering the importance they had in data collection and to purposely get the intended detail. On the other hand, observations enabled the researcher to observe what was happening in the natural setting. Data in its natural form was cardinal for making the final inferences of the research. It is strongly believed that these methods provided a conducive environment for an easy and free flow of data.

\subsection{Data Collection Bias}

Biasness in research occurs when the researcher tries to influence the results of their work in order to get the outcome they want. However, the researchers in their own cognizance interpreted all the data collected irrespective of the importance. This meant that each piece of data collected was given the importance in the research. 
Journal of Education and Practice

ISSN 2520-467X (Online)

Vol.5, Issue No.2, pp 1 - 17, 2021

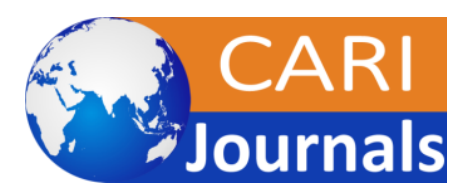

www.carijournals.org

\subsection{Data Analysis}

Themes for data analysis were identified within the qualitative data (Maguire, 2017). The data was analysed using the software called Qualitative Data Analysis (QDA) Miner Lite and manually. Thematic analysis was used to analyse data that was gathered for the study, obtained from interviews and observations. Using the collected data, codes were formulated then transformed into themes and subthemes for comparability. Suffice to mention that content analysis was subject to increased error

\subsection{Trustworthiness}

The findings of this research are credible because of the nature of the sample that was selected for the interviews. Meanwhile, the recorded raw data meant the information obtained was not tempered with therefore providing a true meaning to what is happening during lesson presentations. In this view the findings from the research can be transferable thus they can be applied in different contexts. The findings are typically based on the responses from the respondents, the conclusion therefore are not skewed towards the researchers' biasness.

\subsection{Ethics}

Important to say that research ethics are critical because they provide formal safety of the members (Noien \& Talbert, 2011) \& (Marczyk, et al, 2005). The researchers strived within their means to create an enabling atmosphere for the interviews. The importance of ethics should not be disregarded in any research, due to the bad outcomes it may bring on participants. All participants were explained about the research objectives, and an assurance was given that the answers they provided were for academic purpose, and this research.

\subsection{Limitations}

The study was constrained in so many aspects some of which are discussed below:

The research did not cover the entire country "Zambia". This did not happen that way because of the vastness of the country coupled with limited resources. This did not however stop the research from being carried out. Furthermore, the effect of corona virus meant that data was collected quickly so that we maintain the school calendar in relation to the study. Also, the closure announcement of the schools meant that data was to be collected quickly.

When the documented records were requested one teacher failed to provide the file to check what he does. This created a gap in what the research needed to collect.

\subsection{RESULTS AND DISCUSSIONS}

From the content and thematic analysis four themes were yielded from the interview manuscripts. The identified themes from the manuscripts are:

i. application of prescribed pedagogy

ii. teacher content 
Journal of Education and Practice

ISSN 2520-467X (Online)

Vol.5, Issue No.2, pp 1 - 17, 2021

www.carijournals.org

\subsection{Application of Prescribed Pedagogy}

In earnest, a teacher's comprehension of pedagogical knowledge enables them to apply the pedagogies as required (Saleh, Rasul \& Affadi, 2018). Thus, good application of the group activities demands that the teacher has knowledge and skills in the subject area. From the findings, competencies in the syllabus are a requirement for teachers to apply the prescribed pedagogies suitably. Sadly, teachers did not know the competencies that are spelt out in the design and technology syllabus. The implication of this is that they cannot apply the prescribed pedagogy as required in their teaching. Therefore, the study can insinuates that even the teacher practices are not at the level expected. The competencies indicated in the syllabus are investigative, interpretative, application, communication, valuing, and participating skills (Ministry of Education S. V., 2013). But it is important point that the teachers have the duty to familiarise themselves with the new curriculum..

The findings further indicate that some teachers are aware of the contents of the syllabus although a good number needs to be encouraged to acquaint themselves with its content. Knowing the contents of the syllabus translate to good application of the prescribed pedagogies. It is also evident that of the massive orientation of the syllabus is ideal for all concerned teachers.

It came that the choice of pedagogy is dependent on the type of the lesson. What is critical also is to consider the learners' intellectual abilities. This is because a good approach if applied without learner intellectual consideration may fail to address the intended outcomes.

If the teacher fails to interpret the contents of the syllabus, they cannot accordingly apply the pedagogies. Thus, there is a need for an organised orientation of the syllabus and deepening the understanding of the prescribed pedagogy to enhance the teacher practices for design and technology. As a consequence, application of the pedagogy will improve.

\subsection{Pedagogy Choice}

For any lesson presentation there is need to choose a pedagogy that will produce necessary results. Thus, this underscores the importance of the teachers understanding the pedagogies that are provided in the syllabus. Interestingly teachers have the pedagogies that they like to apply for teaching of design and technology. However, it is important to point out that pedagogy choice is as a result of a number of reasons which may include the nature of the lesson and the environment. The pedagogy applied need to be clear enough for leaners to follow the steps provided (: Saleh, 2018). The teacher needs to present to learners a lesson in an orderly manner, and this can only be achieved one understands the pedagogy they are applying. From the practical presentation of lesson it shows that teachers are more facilitators in lesson delivery. This exceedingly shows that the application of the pedagogies is in line with what the syllabus demands for. The response makes one doubt if the teachers understood the pedagogies in the syllabus this is because they brought out other pedagogies that are not part of the prescribed methods. These include verbal exposition and question and answer 
Journal of Education and Practice

ISSN 2520-467X (Online)

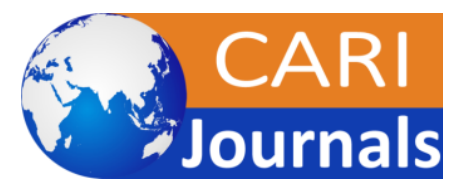

Vol.5, Issue No.2, pp 1 - 17, 2021

WwW.carijournals.org

The teachers provided different reasons for not using the pedagogies in the syllabus. The common reason given was lack of funding, non-availability of transport and few places to visit, truly other teachers are widely aware while others are not.

\subsection{Pupils’ Response Discussion}

The pupils pointed out those lessons were mostly presented through verbal exposition. This on its own is a problem to assess the skill they teach without the practical activities. This compromised the recommended approaches for teaching design and technology. In fact, theoretical method is not on the list of the prescribed pedagogies for design and technology but it could be applied because it is an easy way to teach. The common method of choice are demonstration, group work, discussion and research are the pedagogy their teachers use. They explained that their teachers give a topic to research on, this is followed by group presentations and the teacher then summarizes. This is encouraging, the researcher feels all it needs enhancement so that the variety of the pedagogies in the syllabus is extensively explored.

\subsection{Conclusion}

Good pedagogical application and teacher practices provide the base of good skill sustainability and application in day to day livelihood of learners. It is assumed that the development of the syllabus with its detail and the guide in terms of the intended outcomes teachers would appropriately apply the proposed pedagogies in the syllabus. The inability for teachers to understand and interpret the detail in the curriculum framework and the national syllabus results in failure to cognize the tenets and its requirements.

The findings from the research recognised that teachers of Design and Technology teachers are aware of the pedagogies that are recommended for the teaching of the subject. It further established that teachers lack the detail of the content they are supposed to use when teaching Design and Technology. The interpretation of this is that teachers lack an in-depth understanding of what they are supposed to deliver. As a consequence, the learners fail to apply the knowledge as expected in the curriculum. This is because the teaching is not sufficient to acquire the nittygritty of the skill. Teachers need to be provided with these competencies for a good application of pedagogies

The result from such is avoiding demonstrations for fear of being embarrassed in front of the leaners. On the whole, if the teacher fails to demonstrate, learners may be impacted negatively because the teacher does not provide the model as required. Moreover, the findings have shown that teachers intend to apply a variety of approaches that are in the syllabus but resources impede them. This is beyond them and the best they can do is to keep on looking on alternative ways to appropriately teach. Understandably, this is not easy with economic difficulty though teachers are encouraged to be resourceful.

Additionally, it is evident that the application of the PCK framework plays a crucial role in the choice and use of the pedagogy appropriately. The use of the frameworks identified in this 
Journal of Education and Practice

ISSN 2520-467X (Online)

Vol.5, Issue No.2, pp $1-17,2021$

research will indeed improve teacher application of prescribed pedagogy as it was observed by Jalbani, (2014). Likewise, understating the recommended curriculum frameworks by teachers is vital if they are to teach effectively. This comprehension will enable the teacher to have a reflection on how they teach.

\subsection{Contribution to Theory Policy and Practice}

Practicing teacher need to read to take time to read the curriculum after they have been introduced. This will make them understand the pedagogies that that has been introduced to teach the subject. However this can be enhanced through localised training programs such the continuous professional development programs and capacity building workshops. Additionally, there should be a deliberate policy for in service training programs before the program is rolled out and after.

\subsection{Recommendations}

Based on the findings and conclusion the following recommendations are suggested:

1. Ministry of General Education should capacity build teachers in material production so they can ably apply prescribed pedagogies when teaching D\&T, besides the provision of teaching and learning materials.

2. The industrial arts trained teachers need to be retrained therefore, the government should put up the policy with a target period of seeing them retrained.

3. To expertly articulate prescribed pedagogies in the syllabus the teachers need to read the policy documents such as the national curriculum framework to make themselves conversant with the requirements.

4. The study was undertaken using qualitative approach, there is need that a quantitative or mixed approach is applied and to broaden the area of study so that the findings are generalised.

\section{REFERENCES}

Astalin, K. P. (2013). Qualitative Research Designs: A Conceptual Framework. International Journal of Social Science \& Interdisciplinary Researc, ISSN 2277- 3630 hIJSSIR, Vol.2 (1), pp 118-122.

Bell, D. Wooff, D. Mclain, M \& Morrison, D. (2017, March 02). Analysing Designand Technologyas an educational construct; An invetigationginto its curriculumposition and peddagogical identity. Retrieved May 02, 2019, from BERA: http://www.bera.ac.uk

Broom, C. (2015). Empoering students: Pedagogy that benefits education and learners. Citizenship, Social and Economic Education, Vol. 14(2) , 79-86.

Carbonilla Gorra \& Bhati. (2016). Students' perception on use of technology in the classroom at higher education institutions in Philippines. Asian Journal of Education and e-Learning, 4 (3), 92-103. 
Journal of Education and Practice

ISSN 2520-467X (Online)

Vol.5, Issue No.2, pp 1 - 17, 2021

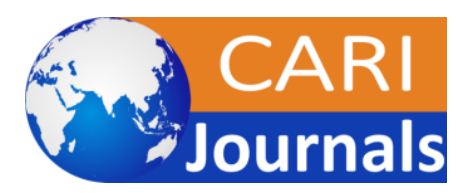

www.carijournals.org

Cedefop, \& Cedefop. (2015). Vocational pedagogies and benefits for learners: practices and challenges in Europe. Luxembourg: Publications Office of the European Union.

Eady \& Lockyer. (2013). Tools for learning: technology and teaching strategies', Learning to Teach in the Primary School. University of Wollongong, Research Online, 71.

Gaotlhobogwe, M. (2014). A comparative analysis of patterns of girls ' attitudes towads design and technology: Botswanaand Swaziland. austrlian Journal of Technology Education, Volume 1.

Haynes, L. (2008). Studyng STEM: What sre the barriers? Wales: The Instituteof Engineering Technology.

Husbands, C. \&. (2012). What makes great pedagogy? Nine claims from research. National College for School Leadership, 4.

Jalbani, N. (2014). The Impact of Effective Teaching Strategies on the Students' Academic Performance and Learning Outcome. Munich: GRIN Verlag, https://www.grin.com/document/300046.

Kafyulilo, Rugambuka, (2013) \& Makunja, (2015)). (2018). Pedagogical Practices of Design and Technology Teacher Trainees. International Journal of Academic Research in Business and Social Sciences, Vol. 8 , No. 5, 320-327.

Kafyulilo, A. C., Rugambuka, I. B. \& Moses, I. (2013). Implementation of Competency Based Teaching in Morogoro Teachers' Training College, Tanzania. Makerere Journal of Higher Education, 312.

Kelley \& Kellam. (2009). A Theoretical Framework to Guide the ReEngineering of Technology Education. Journal of Technology Education, Vol. 20 No. 2, 37-45.

Kelly, M. J. (1999). Origins of education in zambia. Lusaka.

Khunyakari, R. P. (2015). Experiences of design-and-make interventions with indian middle school students. Contemporary Education Dialogue, 12 (2), DOI: 10.1177/0973184915581916, 139-176.

Koehler \& Mishra. (2005). What happens when teachers design educational technology? The development of technological pedagogical content knowlegde. J. Educational Computing Research, Vol. 32(2) 131-152, 2005, 131-152.

Kushner, Benson \& Ward. (2013). Teaching with technology: Using TPACK to understand and teaching using expertise in online higher education. J. Educational Computing Research, Vol. 48(2), 153-172.

Lucas, B. (2014). Vocational Pedagogy What it is, why it matters and what we can do about it . Centre for Real-World Learning, 2. 
Journal of Education and Practice

ISSN 2520-467X (Online)

Vol.5, Issue No.2, pp $1-17,2021$

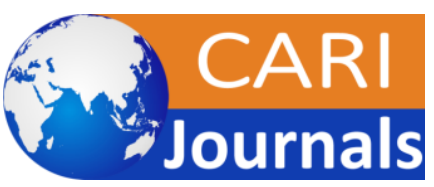

$\underline{\text { www.carijournals.org }}$

Makunja, G. (2015). Adopting Competence-Based Curriculum to Improve Quality of Secondary Education in Tanzania: "Is it a Dream or Reality"? International Journal of Education and Research, Vol. 3 No. 11 November, 175.

Ministry of Education. (1996). Educating Our Future: Nationl Policyon education. Lusaka: Zambia Educstional Publishing House.

Ministry of Education, S. V. (2013). Design and technolog syllabus grade 8-9. Lusaka: Curriculum Develoment Center.

Morgan, et al. (2013). New Principles for Design \& Technologyin the National Curriculum. London: E4E.

Mukereredzi, T. (March 2019). SADC meeting agrees on need for STEM in industrialisation. Univesity World News.

Ngendahayo \& Askell-Williams. (2010). How might the $\mathrm{M}$ in STEM relate to the T in STEM when the T in STEM is D\&T? Mathematics in School, Vol. 39, No., pp. 31-33, 31-33.

Nkanza, P. K. (2014). Policy, Practice and Research in Teacher Professional Growth. Zambia Journal of Teacher Profssional Growth Vol 2, Nol, 1-5.

OECD. (2009). Creating Effective Teaching and Learning Environments: First Results from TALIS . 75775 Paris Cedex 16: OECD.

OECD. (2014, October). Retrieved April 29th, 2019, from http://www.oecd.org/edu/policyoutlook.htm

Pamies, J., Blanco, A., Sanchez, J.G. \& Villanueva. (2015). The introduction of a competence based curriclum in Spain from the primary to the teacher training. An independent scientifi c journal, 62-67.

SADC. (June 2018). SADC Ministers responsible for educatuion and training science and technologyand innovationministerial policy dialogue. Southern Africa Development Community.

Saleh, Rasul \& Affadi. (2018). Pedagogical practices of design and technology teacher trainees. International Journal of Academic Research in Business and Social Sciences Vol. 8, No. 5, 320-327.

Schunk, D. (2012). Learning Theoriesan Educational Perspective . London: Pearson.

The Ministry of General Education \& Ministry of Hi. (2016). Education and Skills Sector Plan 2017-2021. Lusaka: Government printers.

UNESCO. (2014). Education Systems in ASEAN+6 Countries: A Comparative Analysis of Selected Educational Issues. Bangkok: United Nations Educational, Scientific and 
Journal of Education and Practice

ISSN 2520-467X (Online)

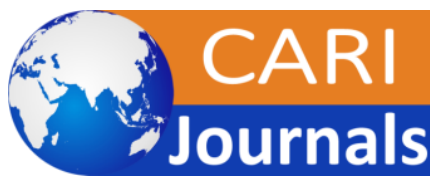

Vol.5, Issue No.2, pp 1 - 17, 2021

www.carijournals.org

Cultural Organization 7, place de Fontenoy, 75352 Paris 07 SP, France and Bangkok office.

Williams, J. P. (2012). Technologye education for teachers. Rotterdam: Sense Publishers. 